\title{
Stimulation of Erythrocyte Cell Membrane Scrambling by C-Reactive Protein
}

\author{
Majed Abed ${ }^{\mathrm{a}}$ Christian Thiel $^{\mathrm{b}}$ Syeda T. Towhid ${ }^{\mathrm{a}}$ Kousi Alzoubia Sabina Honisch ${ }^{\mathrm{a}}$ \\ Alfred Königsrainer ${ }^{\mathrm{b}}$ Florian Lang ${ }^{\mathrm{a}, \mathrm{c}}$ \\ aDepartment of Internal Medicine III, bepartment of General, Visceral and Transplant Surgery, \\ Eberhard-Karls-University of Tuebingen, Tuebingen, 'Department of Molecular Medicine II, Medical \\ Faculty, Heinrich Heine University, Duesseldorf, Germany
}

\section{Key Words}

Phosphatidylserine - Calcium - Cell volume - Eryptosis - Inflammation - C-reactive protein • Appendicitis

\begin{abstract}
Background: Eryptosis, the suicidal erythrocyte death characterized by cell shrinkage and phosphatidylserine-translocation, is triggered by fever and inflammation. Signaling includes increased cytosolic $\mathrm{Ca}^{2+}$-activity $\left(\left[\mathrm{Ca}^{2+}\right]_{\mathrm{i}}\right)$, caspase activation, and ceramide. Inflammation is associated with increased plasma concentration of C-reactive protein (CRP). The present study explored whether CRP triggers eryptosis. Methods: Phosphatidylserine abundance at the cell surface was estimated from annexin-V-binding, cell volume from forward scatter, $\left[\mathrm{Ca}^{2+}\right]_{\mathrm{i}}$ from Fluo3-fluorescence, ceramide abundance and caspase-3-activity utilizing FITC-conjugated antibodies. Moreover, blood was drawn from patients with acute appendicitis $(9 \circ, 11 \hat{\jmath})$ and healthy volunteers $(10+10 \hat{)})$ for determination of CRP, blood count and phosphatidylserine. Results: A 48h CRP treatment significantly increased the percentage of annexin-V-binding cells $(\geq 5 \mu \mathrm{g} / \mathrm{ml}),\left[\mathrm{Ca}^{2+}\right]_{\mathrm{i}}(\geq 5 \mu \mathrm{g} / \mathrm{ml})$, ceramide $(20 \mu \mathrm{g} / \mathrm{ml})$ and caspase-activity $(20 \mu \mathrm{g} / \mathrm{ml})$. AnnexinV-binding was significantly blunted by caspase inhibitor zVAD $(10 \mu \mathrm{M})$. The percentage of phosphatidylserine-exposing erythrocytes in freshly drawn blood was significantly higher in appendicitis patients $(1.83 \pm 0.21 \%)$ than healthy volunteers $(0.81 \pm 0.09 \%)$, and significantly higher following a $24 \mathrm{~h}$ incubation of erythrocytes from healthy volunteers to patient plasma than to plasma from healthy volunteers. The percentage of phosphatidylserine-exposing erythrocytes correlated with CRP plasma concentration. Conclusion: C-reactive protein triggers eryptosis, an effect at least partially due to increase of $\left[\mathrm{Ca}^{2+}\right]_{i^{\prime}}$ increase of ceramide abundance and caspase activation.

(C) 2017 The Author(s)

Published by S. Karger AG, Basel
\end{abstract}

\section{Introduction}

Upon injury, erythrocytes may undergo suicidal death or eryptosis, which is characterized by cell shrinkage [1] and translocation of phosphatidylserine from the cell interior to the erythrocyte surface [2-4]. Cellular mechanisms triggering eryptosis include oxidative stress [2], increased cytosolic $\mathrm{Ca}^{2+}$ activity $\left(\left[\mathrm{Ca}^{2+}\right]_{\mathrm{i}}\right)[2]$, ceramide [5], energy depletion [2], caspases [2, 6, 7] and the G-protein subunit Gai2 [8]. Moreover, eryptosis may

Prof. Dr. Florian Lang

KARGER
Department of Physiology and Cardiology \& Cardiovascular Medicine, University of Tuebingen, Gmelinstr. 5/Otfried-Mueller-Str. 10, D-72076 Tuebingen (Germany)

Tel. +49 707129 72194, Fax +49 707129 5618, E-Mail florian.lang@uni-tuebingen.de 
be stimulated following activation of casein kinase $1 \alpha$, Janus-activated kinase JAK3, protein kinase C, and/or p38 kinase [2]. Eryptosis is inhibited by AMP activated kinase AMPK, cGMPdependent protein kinase, and PAK2 kinase [2]. Eryptosis is stimulated by a wide variety of small molecules [2, 9-63]. Moreover, eryptosis is enhanced in elderly individuals [64]. It is sensitive to erythrocyte age [65] and enhanced eryptosis is observed following erythrocyte storage $[66,67]$.

Eryptotic erythrocytes are bound to and subsequently engulfed by macrophages and thus rapidly cleared from circulating blood $[2,68]$. Accordingly, excessive eryptosis may lead to anemia [2]. Moreover, eryptotic erythrocytes may bind to endothelial cells of the vascular wall [69], trigger blood clotting and induce thrombosis [70-72], thus interfering with microcirculation [5, 70, 73-76].

A variety of clinical conditions are paralleled by stimulated eryptosis [2-4, 77-84] including fever [85]. Fever is a common complication of appendicitis [86], which is paralleled by an increase of C-reactive protein abundance in plasma [87, 88]. Enhanced CRP plasma levels are valuable markers of inflammation $[89,90]$. C-reactive protein contributes to the host reaction against pathogens and participates in the orchestration of inflammation by interaction with endothelial cells, endothelial progenitor cells, leukocytes and platelets [90]. The inflammatory response is accomplished by pentameric C-reactive protein (pCRP) [89]. C-reactive protein has been shown to trigger suicidal death or apoptosis of nucleated cells [91] and could thus, at least in theory, similarly stimulate eryptosis.

The present study addressed the impact of C-reactive protein on eryptosis. To this end, erythrocytes drawn from healthy individuals were exposed to C-reactive protein and $\left[\mathrm{Ca}^{2+}\right]_{i}$, ceramide abundance and caspase activity were determined. Moreover, blood was drawn from patients with acute appendicitis or erythrocytes from healthy individuals exposed to plasma from appendicitis patients and eryptotic erythrocytes identified by determination of phosphatidylserine exposure.

\section{Materials and Methods}

\section{Patients, erythrocytes and treatments}

Blood was drawn from untreated patients diagnosed with acute appendicitis $(11+, 9 \hat{\sigma}$, age range 22-76 years) and healthy volunteers (10 $\circ, 10 \hat{\delta}$, age 22-69 years). The patients were recruited 2012 and 2013 from the Department of General, Visceral and Transplant Surgery, Tübingen, Germany. The study was approved by the ethics committee of the University of Tübingen $(184 / 2003 \mathrm{~V})$. Both, patients and healthy volunteers provided written informed consent. Measurements were made in freshly isolated erythrocytes or in erythrocytes ( $\mathrm{O}^{-}$blood group) from healthy young individuals incubated in vitro with fresh plasma from either patients or healthy volunteers. Alternatively, fresh Li-Heparin-anticoagulated blood samples were kindly provided by the blood bank of the University of Tübingen. To isolate erythrocytes, blood was centrifuged at 120 $\mathrm{g}$ for $20 \mathrm{~min}$ at $23^{\circ} \mathrm{C}$, the platelets and leukocytes-containing supernatant was disposed, and the erythrocyte pellet washed once with Ringer solution. Erythrocytes were incubated in vitro for 24 hours at a hematocrit of $0.4 \%$ in plasma from patients or healthy volunteers or in Ringer solution containing (in mM) $125 \mathrm{NaCl}, 5$ $\mathrm{KCl}, 1 \mathrm{MgSO}_{4}$, $32 \mathrm{~N}$-2-hydroxyethylpiperazine-N-2-ethanesulfonic acid (HEPES), 5 glucose, and $1 \mathrm{CaCl}_{2}$; the $\mathrm{pH}$ was adjusted to 7.4 and the temperature kept at $37^{\circ} \mathrm{C}$. The low hematocrit was chosen to minimize mutual erythrocyte interaction. Where indicated, erythrocytes were exposed to C-reactive protein (Sigma Aldrich, Hamburg, Germany) at the indicated concentrations.

\section{Annexin-V-binding and forward scatter}

After incubation under the respective experimental conditions, $150 \mu \mathrm{l}$ cell suspension was washed in Ringer solution containing $5 \mathrm{mM} \mathrm{CaCl}_{2}$ and then stained with Annexin-V-FITC (1:200 dilution; ImmunoTools, Friesoythe, Germany) in this solution at $37^{\circ} \mathrm{C}$ for $20 \mathrm{~min}$ under protection from light. In the following, the forward scatter (FSC) of the cells was determined, and annexin-V fluorescence intensity was measured with an excitation wavelength of $488 \mathrm{~nm}$ and an emission wavelength of $530 \mathrm{~nm}$ on a FACS Calibur (BD, Heidelberg, Germany). 


\section{Cellular Physiology Cell Physiol Biochem 2017;41:806-818

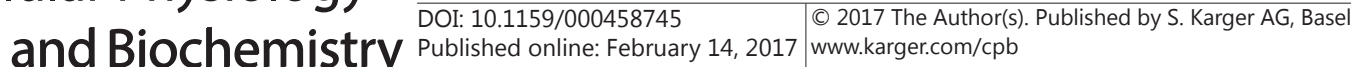

Abed et al:: C-Reactive Protein and Eryptosis

Intracellular $\mathrm{Ca}^{2+}$

After incubation under the respective experimental conditions, $150 \mu \mathrm{l}$ cell suspension was washed in Ringer solution and then loaded with Fluo-3/AM (Biotium, Hayward, USA) in Ringer solution containing 5 $\mathrm{mM} \mathrm{CaCl}$ and $5 \mu \mathrm{M}$ Fluo-3/AM. The cells were incubated at $37^{\circ} \mathrm{C}$ for $30 \mathrm{~min}$ and washed twice in Ringer solution containing $5 \mathrm{mM} \mathrm{CaCl}_{2}$. The Fluo-3/AM-loaded erythrocytes were resuspended in $200 \mu$ l Ringer. $\mathrm{Ca}^{2+}$-dependent fluorescence intensity was measured with an excitation wavelength of $488 \mathrm{~nm}$ and an emission wavelength of $530 \mathrm{~nm}$ on a FACS Calibur.

\section{Ceramide abundance}

To determine ceramide abundance, a monoclonal antibody-based assay was used. After incubation, cells were stained for $1 \mathrm{~h}$ at $37^{\circ} \mathrm{C}$ with $1 \mu \mathrm{g} / \mathrm{ml}$ anti-ceramide antibody (clone MID 15B4; Alexis, Grünberg, Germany) in phosphate-buffered saline (PBS) containing $0.1 \%$ bovine serum albumin (BSA) at a dilution of 1:10. After two washing steps with PBS-BSA, cells were stained for 30 min with polyclonal fluoresceinisothiocyanate (FITC)-conjugated goat anti-mouse IgG and IgM specific antibody (BD Pharmingen, Hamburg, Germany) diluted 1:50 in PBS-BSA. Unbound secondary antibody was removed by repeated washing with PBS-BSA. Samples were then analyzed by flow cytometric analysis at an excitation wavelength of $488 \mathrm{~nm}$ and an emission wavelength of $530 \mathrm{~nm}$.

\section{Confocal microscopy}

For the visualisation of eryptotic erythrocytes, $20 \mu \mathrm{l}$ of erythrocyte suspension were incubated in respective experimental conditions and stained with Annexin-V-FLUOS (1:100 dilution; Roche Life Sciences, Germany) in $200 \mu$ l Ringer solution containing $5 \mathrm{mM} \mathrm{CaCl}_{2}$. Then the erythrocytes were washed twice and finally resuspended in $100 \mu \mathrm{l}$ Ringer solution. A volume of $40 \mu \mathrm{l}$ cell suspension was smeared onto glass slides. After 15 min drying at RT, the slides were mounted with Prolong Gold antifade reagent (Invitrogen, Darmstadt, Germany) and covered with a coverslip. Images were subsequently taken on a Zeiss LSM 5 EXCITER confocal laser scanning microscope (Carl Zeiss MicroImaging, Oberkochen, Germany) with water immersion Plan-Neofluar 40/1.3 NA DIC.

\section{Caspase activity}

Abundance of active caspase-3 was detected according to the manufacturer's instruction of CaspGlow Fluorescein Active Caspase-3 Staining kit from BioVision (CA, USA). Briefly, cells were treated as mentioned before including a negative control with $10 \mu \mathrm{M}$ Z-VAD-FMK. Subsequently $150 \mu$ l cell suspentions were transferred to a 96-well plate, centrifuged at $1600 \mathrm{rpm}$ for $4 \mathrm{~min}$, and washed once with wash buffer solution followed by staining with $1 \mu \mathrm{l}$ FITC-DVD-FMK for $1 \mathrm{~h}$ at $37^{\circ} \mathrm{C}$. Stained cells were washed once, resuspended in $200 \mu \mathrm{l}$ wash buffer and measured immediately with an excitation wavelength of $488 \mathrm{~nm}$ and an emission wavelength of $530 \mathrm{~nm}$ on a FACS Calibur (BD, Heidelberg, Germany).

\section{Statistics}

Data are expressed as arithmetic means \pm SEM. As indicated in the figure legends, statistical analysis was made using ANOVA with Tukey's test as post-test and $t$ test as appropriate. $\mathrm{n}$ denotes the number of different erythrocyte specimens studied. Since different erythrocyte specimens used in distinct experiments are differently susceptible to triggers of eryptosis, the same erythrocyte specimens have been used for control and experimental conditions.

\section{Results}

The present study explored whether C-reactive protein could trigger eryptosis of erythrocytes drawn from healthy volunteers. As illustrated in Fig. 1A,B, a 24 h exposure of erythrocytes isolated from healthy volunteers to C-reactive protein increased the percentage of phosphatidylserine exposing erythrocytes, an effect reaching statistical significance at 5 $\mu \mathrm{g} / \mathrm{ml} \mathrm{C}$-reactive protein. The exposure to C-reactive protein did not significantly modify erythrocyte forward scatter (Fig. 1C,D). In order to test whether C-reactive protein interferes with erythrocyte shrinkage following increase of cytosolic $\mathrm{Ca}^{2+}$ activity $\left(\left[\mathrm{Ca}^{2+}\right]_{\mathrm{i}}\right)$, erythrocytes 


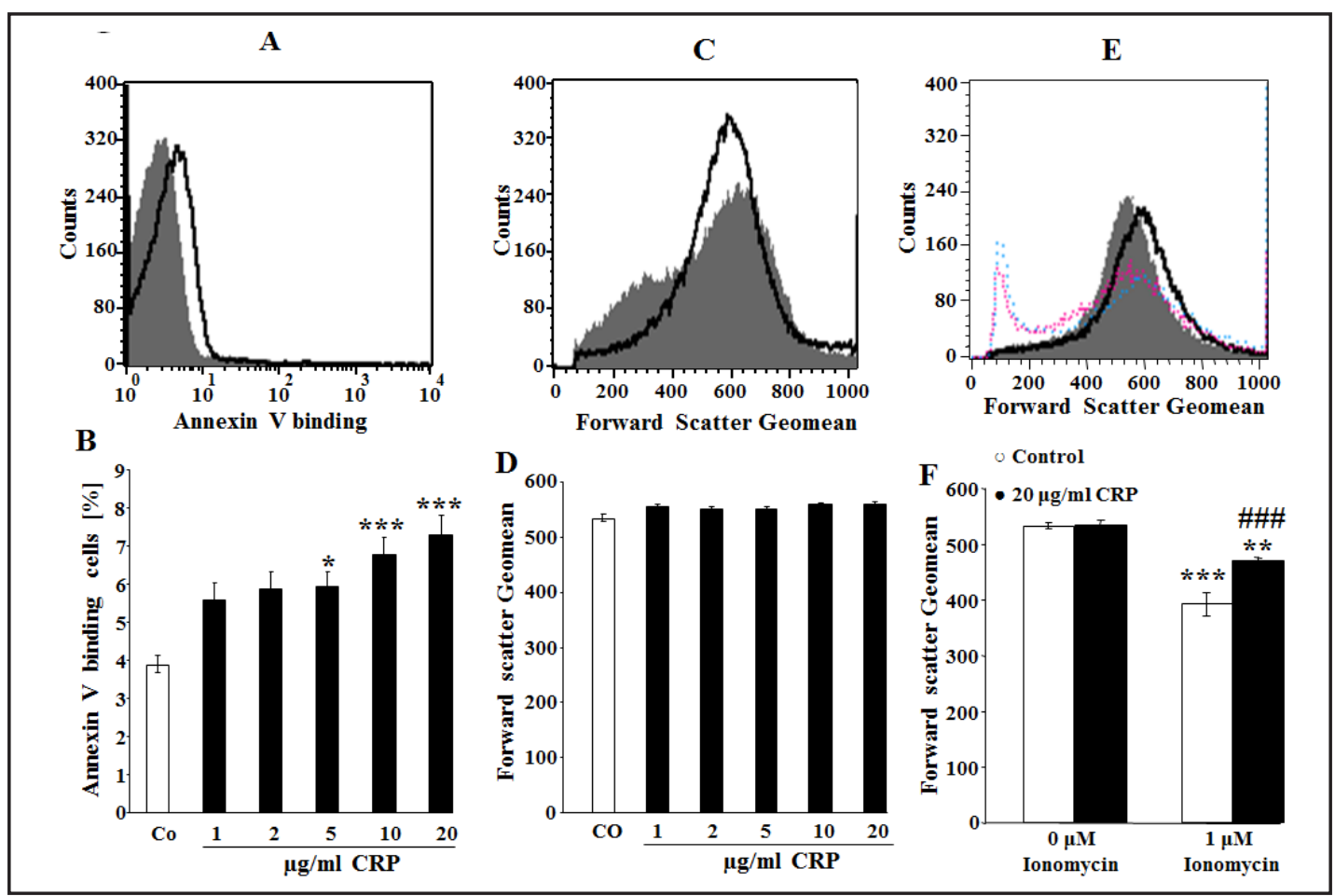

Fig. 1. Effect of C-reactive protein on phosphatidylserine exposure and forward scatter. A. Original histogram of annexin-V-binding of erythrocytes following exposure for $48 \mathrm{~h}$ to Ringer solution without (grey area) and with (black line) presence of $20 \mu \mathrm{g} / \mathrm{ml} \mathrm{C-reactive} \mathrm{protein} \mathrm{B.} \mathrm{Arithmetic} \mathrm{means} \pm$ SEM $(\mathrm{n}=16)$ of erythrocyte annexin-V-binding following incubation for $48 \mathrm{~h}$ to Ringer solution without (white bar) or with (black bars) presence of C-reactive protein $(1-20 \mu \mathrm{g} / \mathrm{ml})$. C. Original histogram of forward scatter of erythrocytes following exposure for $48 \mathrm{~h}$ to Ringer solution without (grey area) and with (black line) presence of $20 \mu \mathrm{g} / \mathrm{ml} \mathrm{C}$-reactive protein. D. Arithmetic means \pm SEM $(\mathrm{n}=16)$ of the erythrocyte forward scatter (FSC) following incubation for $48 \mathrm{~h}$ to Ringer solution without (white bar) or with (black bars) C-reactive protein $(1-20 \mu \mathrm{g} / \mathrm{ml}) .{ }^{*}(\mathrm{p}<0.05),{ }^{* * *}(\mathrm{P}<0.001)$ indicate significant difference from the absence of C-reactive protein (ANOVA). E. Original histogram of forward scatter of erythrocytes following exposure for $48 \mathrm{~h}$ to Ringer solution without (grey area) and with (solid line) presence of $20 \mu \mathrm{g} / \mathrm{ml} \mathrm{C-reactive} \mathrm{protein} \mathrm{alone,} \mathrm{with} \mathrm{(red}$ dotted line) presence of $1 \mu \mathrm{M}$ ionomycin alone and with (blue dotted line) presence of $20 \mu \mathrm{g} / \mathrm{ml} \mathrm{C}$-reactive protein and $1 \mu \mathrm{M}$ ionomycin. F. Arithmetic means \pm SEM $(n=16)$ of the erythrocyte forward scatter (FSC) following incubation for $48 \mathrm{~h}$ to Ringer solution without (white bar) or with (black bars) C-reactive protein (20 $\mu \mathrm{g} / \mathrm{ml})$ in the absence (left bars) and presence (right bars) of ionomycin $(1 \mu \mathrm{M}) .{ }^{* *}(\mathrm{p}<0.01),{ }^{* * *}(\mathrm{P}<0.001)$ indicate significant difference from the absence of $C$-reactive protein, \#\#\# $(\mathrm{P}<0.001)$ indicate significant difference from the absence of ionomycin (ANOVA).

were treated with $\mathrm{Ca}^{2+}$ ionophore ionomycin in the absence and presence of C-reactive protein. As illustrated in Fig. 1E,F, ionomycin decreased forward scatter, an effect significantly blunted in the presence of $\mathrm{C}$-reactive protein.

As illustrated in Fig. 2, the effect of C-reactive protein on phosphatidylserine exposure was paralleled by increase of $\left[\mathrm{Ca}^{2+}\right]_{\mathrm{i}^{*}}$ A $48 \mathrm{~h}$ exposure of erythrocytes isolated from healthy volunteers to C-reactive protein increased the Fluo3 fluorescence (Fig. 2A,B), an effect reaching statistical significance at $5 \mu \mathrm{g} / \mathrm{ml} \mathrm{C}$-reactive protein. The effect of C-reactive protein on annexin-V-binding was significantly blunted in the absence of extracellular $\mathrm{Ca}^{2+}$ (Fig. 2C,D).

Moreover, a $48 \mathrm{~h}$ exposure of erythrocytes isolated from healthy volunteers to C-reactive protein $(20 \mu \mathrm{g} / \mathrm{ml})$ increased the ceramide abundance at the erythrocyte surface (Fig. 3A,B).

As illustrated in Fig. 4A,B, a $48 \mathrm{~h}$ exposure of erythrocytes isolated from healthy volunteers to C-reactive protein $(20 \mu \mathrm{g} / \mathrm{ml})$ was paralleled by a slight, but significant increase 


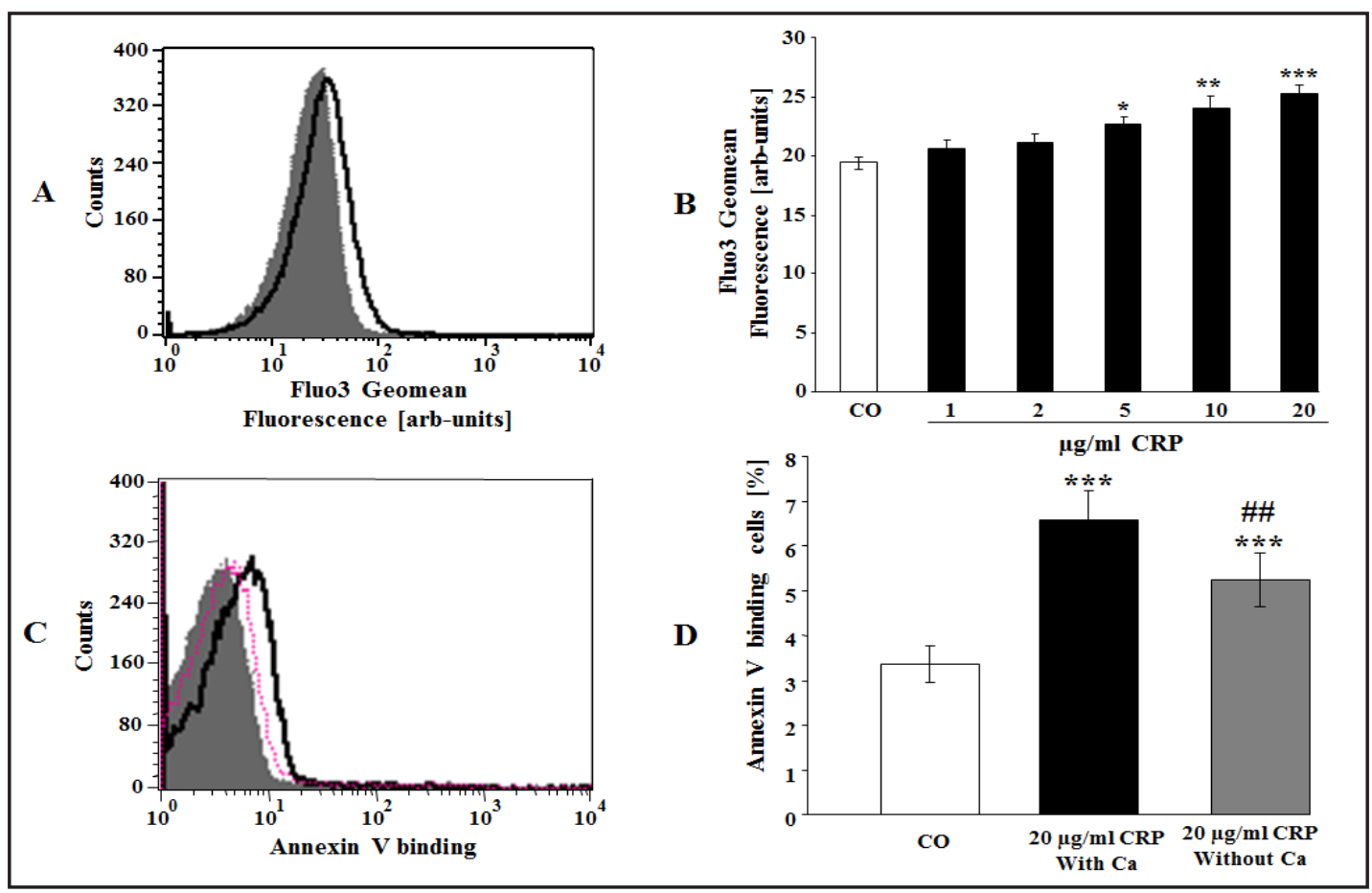

Fig. 2. Effect of $\mathrm{C}$-reactive protein on erythrocyte $\mathrm{Ca}^{2+}$ activity and $\mathrm{Ca}^{2+}$ sensitivity of $\mathrm{C}$-reactive protein induced Annexin V binding. A. Original histogram of Fluo3 fluorescence in erythrocytes following exposure for $48 \mathrm{~h}$ to Ringer solution without (grey area) and with (black line) presence of C-reactive protein $(20 \mu \mathrm{g} / \mathrm{ml})$. B. Arithmetic means \pm SEM $(n=16)$ of the Fluo3 fluorescence (arbitrary units) in erythrocytes exposed for $48 \mathrm{~h}$ to Ringer solution without (white bar) or with (black bars) C-reactive protein $(1-20 \mu \mathrm{g} / \mathrm{ml})$. C. Original histogram of annexin-V-binding of erythrocytes following exposure for $48 \mathrm{~h}$ to Ringer solution without (grey area) and with (solid line) presence of C-reactive protein $(20 \mu \mathrm{g} / \mathrm{ml})$ and presence of extracellular $\mathrm{Ca}^{2+}$ as well as with (dotted line) presence of C-reactive protein $(20 \mu \mathrm{g} / \mathrm{ml})$ and absence of extracellular $\mathrm{Ca}^{2+}$. D. Arithmetic means \pm SEM $(\mathrm{n}=16)$ of erythrocyte annexin-V-binding following incubation for $48 \mathrm{~h}$ to $\mathrm{Ca}^{2+}$ containing Ringer solution without (white bar) or with (black bar) C-reactive protein $(20 \mu \mathrm{g} / \mathrm{ml}$ ) as well as with (grey bars) C-reactive protein $(20 \mu \mathrm{g} / \mathrm{ml})$ in absence of extracellular $\mathrm{Ca}^{2+}$. ${ }^{* *}(\mathrm{P}<0.001)$ indicate significant difference from the absence of $\mathrm{C}$-reactive protein, \#\# $(\mathrm{P}<0.01)$ indicate significant difference from the absence of extracellular $\mathrm{Ca}^{2+}$ (ANOVA).

of caspase-3 activity. The effect of $20 \mu \mathrm{g} / \mathrm{ml}$ C-reactive protein on Annexin-V-binding was significantly blunted in the presence of $10 \mu \mathrm{M}$ caspase inhibitor zVAD (Fig. 4C,D). However, even in the presence of zVAD, C-reactive protein still significantly increased Annexin-Vbinding (Fig. 4D).

In order to test whether the stimulation of eryptosis by C-reactive protein is reflected by the respective modification of eryptosis in inflammatory disorders, blood was drawn from patients with acute appendicitis. As illustrated in Fig. 5, the percentage of erythrocytes exposing phosphatidylserine at the erythrocyte surface was significantly higher in freshly drawn blood from appendicitis patients than in freshly drawn blood from healthy volunteers. Thus, the percentage of phosphatidylserine exposing erythrocytes was enhanced in patients with acute appendicitis.

In order to determine whether the stimulation of phosphatidylserine translocation was due to a plasma-borne factor, erythrocytes isolated from healthy volunteers were exposed to plasma drawn from healthy volunteers or from patients. As shown in Fig. 6, the percentage of erythrocytes isolated from healthy volunteers was significantly higher following a $24 \mathrm{~h}$ exposure to plasma from appendicitis patients than following a $24 \mathrm{~h}$ exposure to plasma from healthy volunteers. Thus, a plasma-borne component contributed to or even accounted for the triggering of phosphatidylserine exposure during appendicitis. 
$\mathbf{A}$

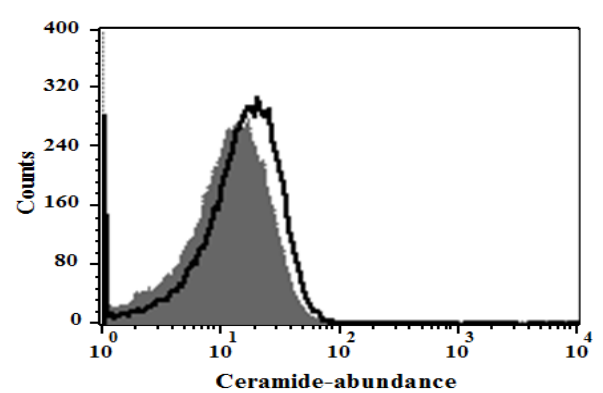

B

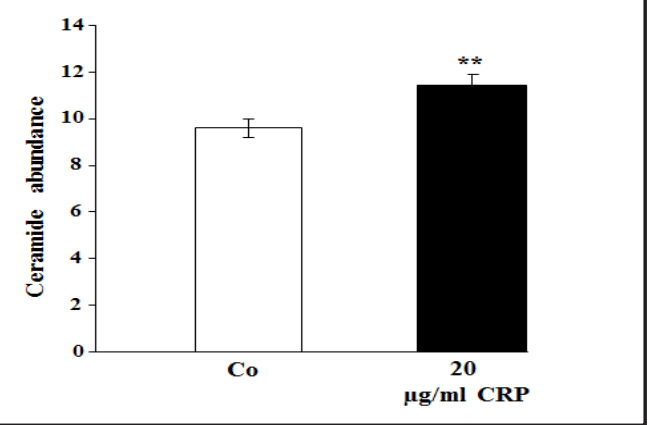

Fig. 3. Effect of C-reactive protein on ceramide abundance. A. Original histogram of ceramide abundance in erythrocytes following exposure for $48 \mathrm{~h}$ to Ringer solution without (grey area) and with (black line) presence of C-reactive protein $(20 \mu \mathrm{g} / \mathrm{ml})$. B. Arithmetic means \pm SEM $(\mathrm{n}=16)$ of ceramide abundance (arbitrary units) in erythrocytes exposed for $48 \mathrm{~h}$ to Ringer solution without (white bar) or with (black bars) C-reactive protein $(20 \mu \mathrm{g} / \mathrm{ml}) .{ }^{*}(\mathrm{p}<0.05),{ }^{* *}(\mathrm{P}<0.01),{ }^{* * *}(\mathrm{P}<0.001)$ indicates significant difference from the absence of C-reactive protein (ANOVA).

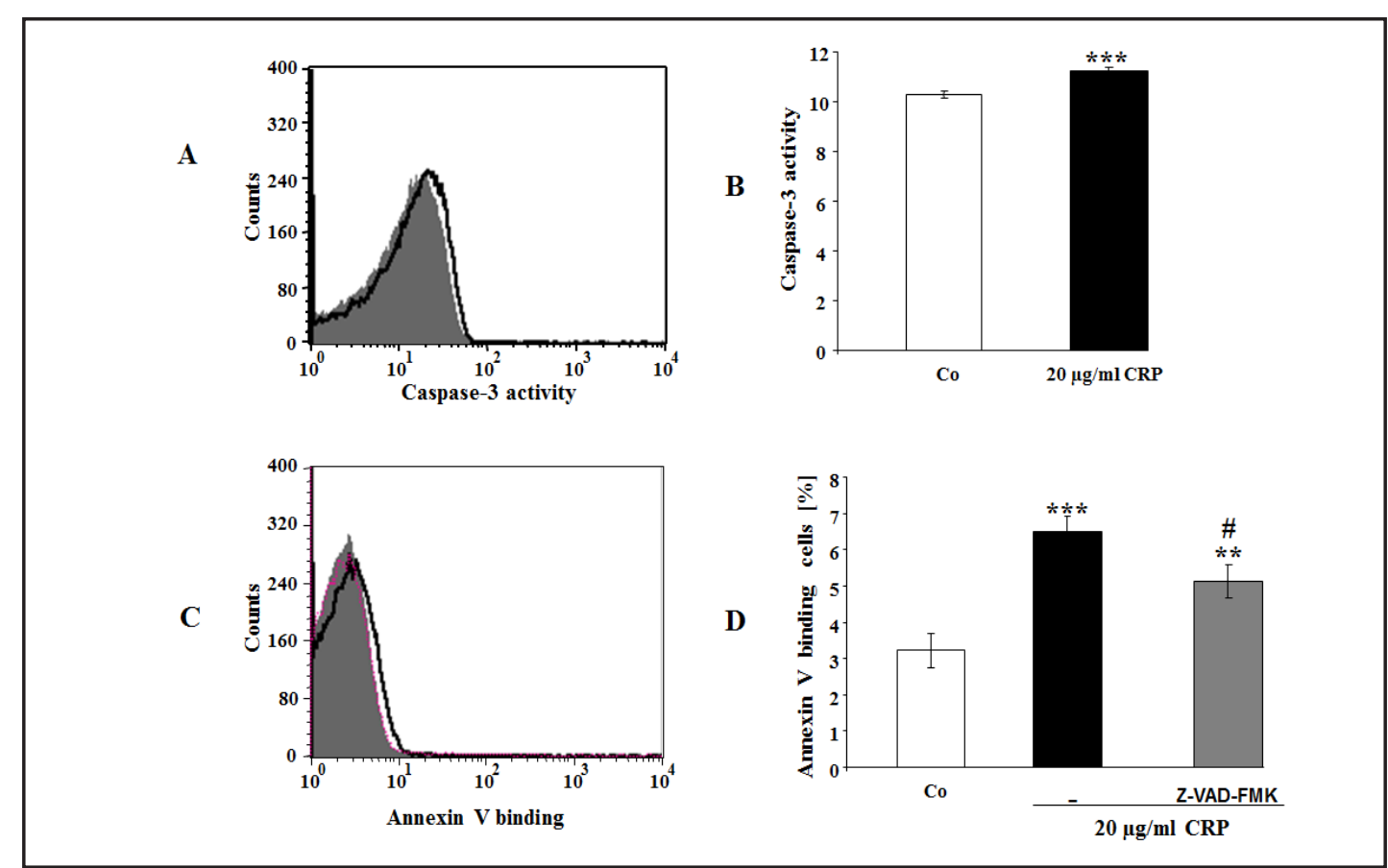

Fig. 4. Effect of C-reactive protein on erythrocyte caspase-3 activity and the influence of caspase inhibitor zVAD on stimulation of annexin-V-binding by C-reactive protein. A. Original histogram of Caspase-3 activity in erythrocytes following exposure for $48 \mathrm{~h}$ to Ringer solution without (grey area) and with (black line) presence of C-reactive protein $(20 \mu \mathrm{g} / \mathrm{ml})$. B. Arithmetic means \pm SEM $(\mathrm{n}=16)$ of the caspase-3 activity (arbitrary units) in erythrocytes exposed for $48 \mathrm{~h}$ to Ringer solution without (white bar) or with (black bars) C-reactive protein $(20 \mu \mathrm{g} / \mathrm{ml}) .{ }^{* *}(\mathrm{P}<0.001)$ indicates significant difference from the absence of $\mathrm{C}$ reactive protein. C. Original histogram of annexin-V-binding of erythrocytes following exposure for $48 \mathrm{~h}$ to Ringer solution without (grey area) and with presence of $20 \mu \mathrm{g} / \mathrm{ml} \mathrm{C-reactive} \mathrm{protein} \mathrm{alone} \mathrm{(solid} \mathrm{line)} \mathrm{or}$ together with caspase inhibitor Z-VAD-FMK (dotted line). D. Arithmetic means \pm SEM $(n=16)$ of erythrocyte annexin-V-binding following incubation for $48 \mathrm{~h}$ to Ringer solution without (white bar) or with presence of C-reactive protein $(20 \mu \mathrm{g} / \mathrm{ml}$ ) alone (black bar) and together with caspase inhibitor Z-VAD-FMK (grey bar). ** $(\mathrm{P}<0.01),{ }^{* * *}(\mathrm{P}<0.001)$ indicates significant difference from the absence of C-reactive protein, \# $(\mathrm{p}<0.05)$, indicates significant difference from the absence of caspase inhibitor Z-VAD-FMK (ANOVA). 


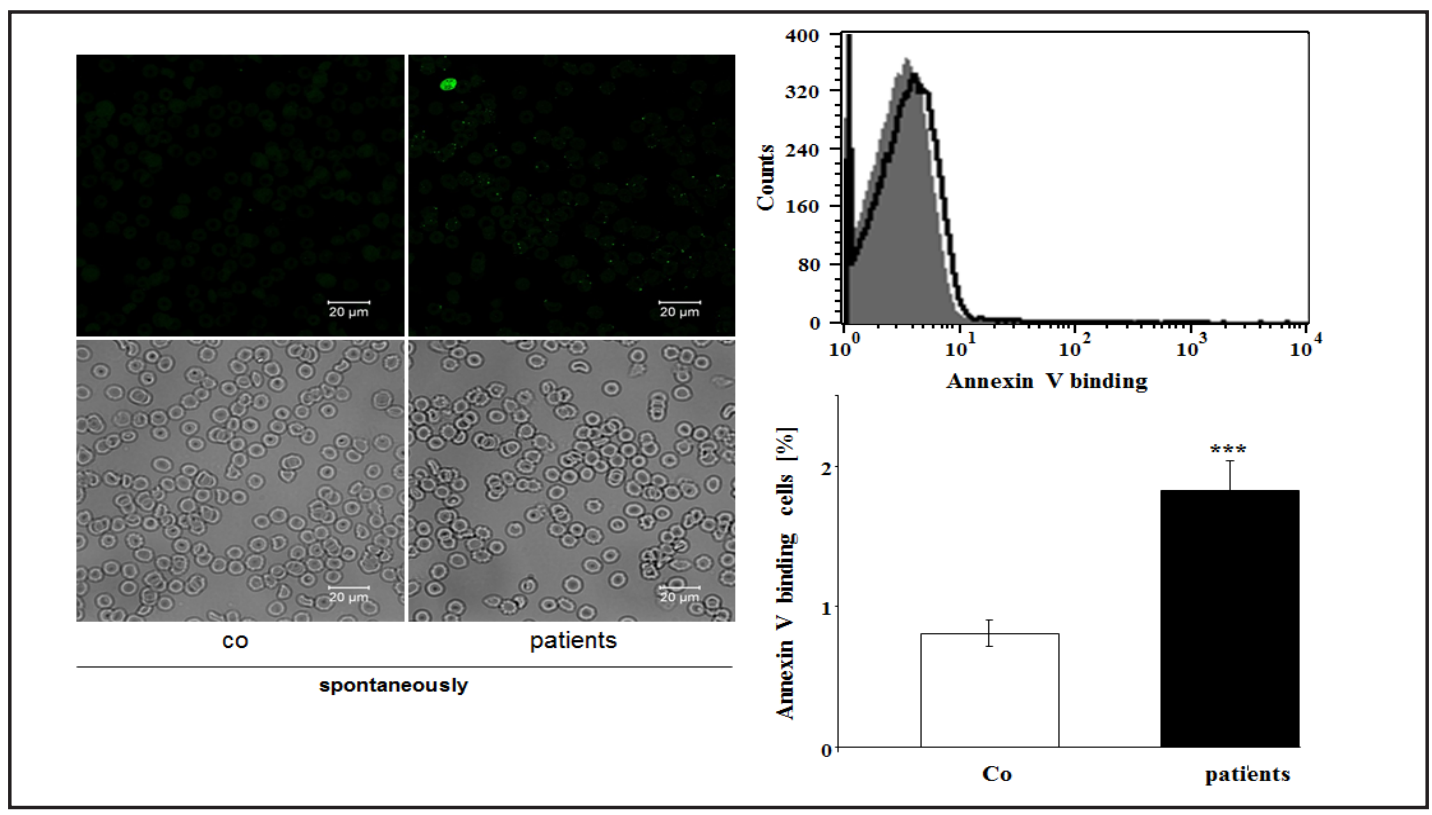

Fig. 5. Phosphatidylserine-exposure of erythrocytes drawn from patients with appendicitis and healthy volunteers . A. Confocal images of human erthrocytes stained with Annexin-V-FLUOS (upper panels) and corresponding light microscopy images (lower panels). The specimens were obtained from a healthy volunteer (left panels) and from a patient with appendicitis (right panels). B. Original histogram of Annexin V-binding of erythrocytes in freshly drawn blood from healthy volunteers (grey area) and from patients (black line). C. Arithmetic means \pm SEM $(\mathrm{n}=9$ 우 11 ) ) of the percentage of Annexin V-binding erythrocytes in freshly drawn blood from healthy volunteers (Control, white bar) and patients (black bar). ${ }^{* * *}(\mathrm{p}<0.001)$ indicates significant difference from healthy volunteers.

As illustrated in Fig. 7, a highly significant $(\mathrm{p}<0.001)$ correlation was observed between $\mathrm{C}$-reactive protein concentration in plasma and the percentage of phosphatidylserine exposing erythrocytes. This observation suggests that $\mathrm{C}$-reactive protein triggers phosphatidylserine translocation or correlates with another parameter stimulating phosphatidylserine translocation.

Accordingly, hemoglobin concentration (Fig. 8A), erythrocyte count (Fig. 8B) and hematocrit (Fig. 8C), but not erythrocyte volume (Fig. 8D) were slightly but significantly lower in appendicitis patients with high levels of C-reactive protein than in appendicitis patients with normal levels of C-reactive protein.

\section{Discussion}

The present observations disclose that C-reactive protein triggers phosphatidylserine translocation in erythrocytes, a key feature of eryptosis, the suicidal erythrocyte death. Exposure of erythrocytes drawn from healthy volunteers to C-reactive protein at concentrations prevailing in plasma from patients with acute appendicitis is followed by significant stimulation of phosphatidylserine translocation.

The C-reactive protein induced phosphatidylserine translocation is paralleled by and at least in part due to increase of cytosolic $\mathrm{Ca}^{2+}$ activity $\left(\left[\mathrm{Ca}^{2+}\right]_{\mathrm{i}}\right)$. The increase of $\left[\mathrm{Ca}^{2+}\right]_{i}$, were further expected to activate $\mathrm{Ca}^{2+}$ sensitive $\mathrm{K}^{+}$channels, $\mathrm{K}^{+}$exit, cell membrane hyperpolarization, $\mathrm{Cl}^{-}$exit and thus cellular loss of $\mathrm{KCl}$ with osmotically obliged water [1]. However, C-reactive protein did not significantly modify erythrocyte forward scatter. Possibly, C-reactive protein, besides increasing $\left[\mathrm{Ca}^{2+}\right]_{\text {; }}$, interferes with cell volume regulation of erythrocytes. Along those lines, the cell shrinkage following exposure to $\mathrm{Ca}^{2+}$ ionophore ionomycin was significantly blunted in the presence of C-reactive protein.

\section{KARGER}




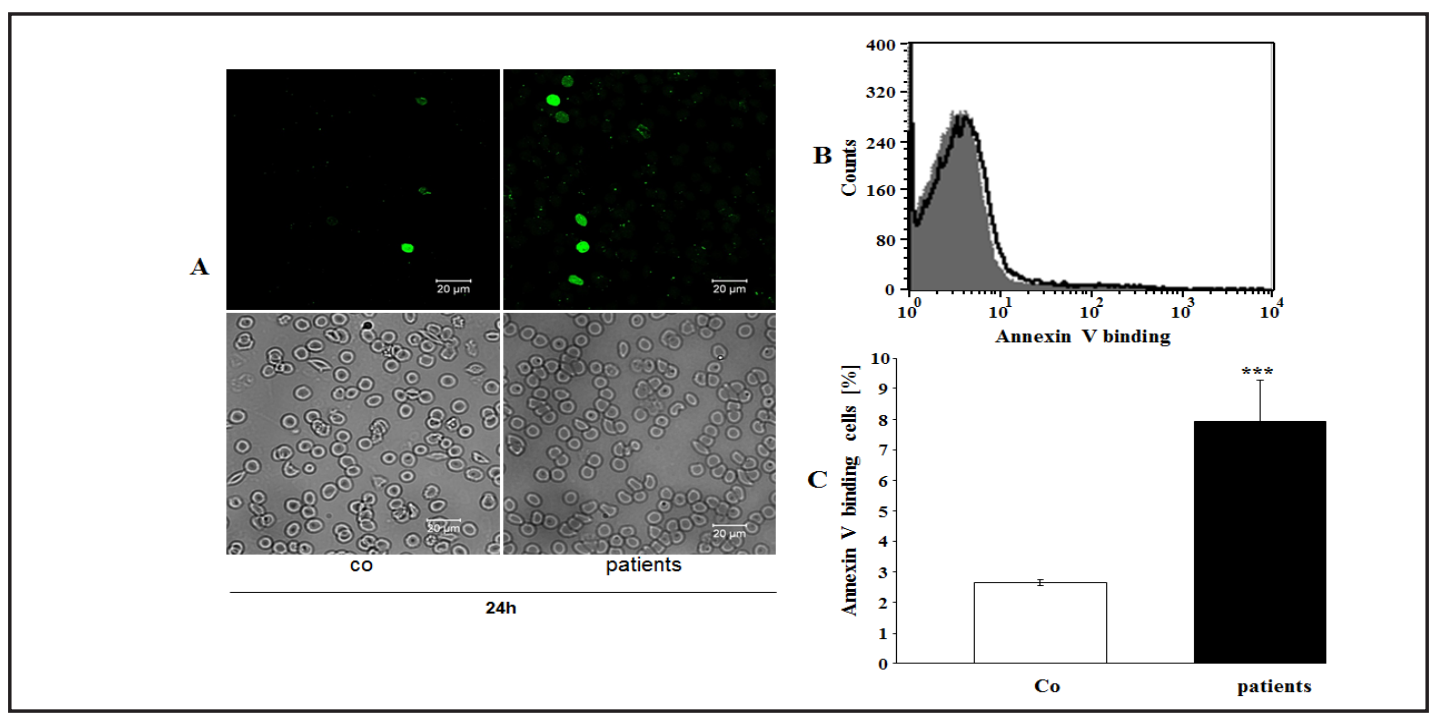

Fig. 6. Phosphatidylserine-exposure of erythrocytes drawn from healthy volunteers and exposed 24 hours to plasma from either patients with appendicitis or healthy volunteers. A. Confocal images of human erythrocytes stained with Annexin-V-FLUOS (upper panels) and corresponding light microscopy images (lower panels). The erythrocytes were obtained from a healthy volunteer and exposed 24 hours to plasma from a healthy volunteer (left panels) and to plasma from a patient with appendicitis (right panels). B. Original histogram of Annexin V-binding of erythrocytes in blood drawn from healthy volunteers exposed for $24 \mathrm{~h}$ to plasma from healthy volunteers (grey area) or to plasma from patients (black line). C. Arithmetic means \pm SEM ( $\mathrm{n}=9$ ㅇ, 11 ) of the percentage of Annexin-V-binding erythrocytes drawn from healthy volunteers and exposed for $24 \mathrm{~h}$ to plasma from healthy volunteers (Control, white bar) or from patients (black bar). ${ }^{* * *}(\mathrm{p}<0.001)$ indicates significant difference from healthy volunteers.

Fig. 7. Annexin-V-binding as a function of C-reactive protein concentration. The percentage annexin-V-binding erythrocytes as a function of C-reactive protein concentration in freshly drawn blood from healthy volunteers (white circles) and patients (black circles).

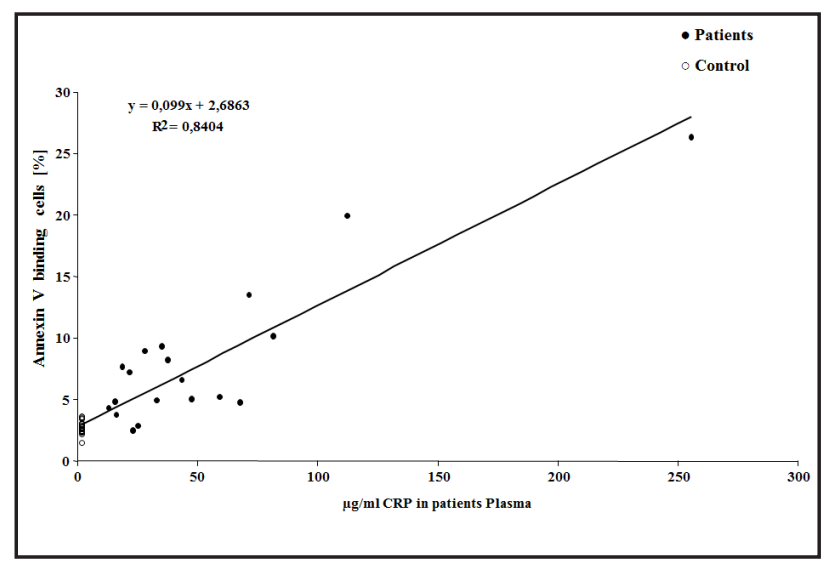

The effect of C-reactive protein on phosphatidylserine translocation was further paralleled by increase of ceramide abundance, which triggers cell membrane scrambling even at normal $\left[\mathrm{Ca}^{2+}\right]_{\mathrm{i}}[2]$. Moreover, C-reactive protein slightly triggers caspase activation. The partial inhibition of phosphatidylserine translocation by caspase inhibitor zVAD suggests that the effect of C-reactive protein on cell membrane scrambling is partially but not fully due to caspase activation.

Considering the in vitro effects of C-reactive protein, it must be kept in mind that in vivo C-reactive protein may interact with other plasma proteins thus modifying its effects. Nevertheless, acute appendicitis is associated with increase of annexin-V-binding reflecting erythrocyte cell membrane scrambling with phosphatidylserine translocation from the cell interior to the erythrocyte surface. The paper further reveals that eryptosis is triggered by a plasma borne component, as it is stimulated by exposure of erythrocytes drawn from healthy 


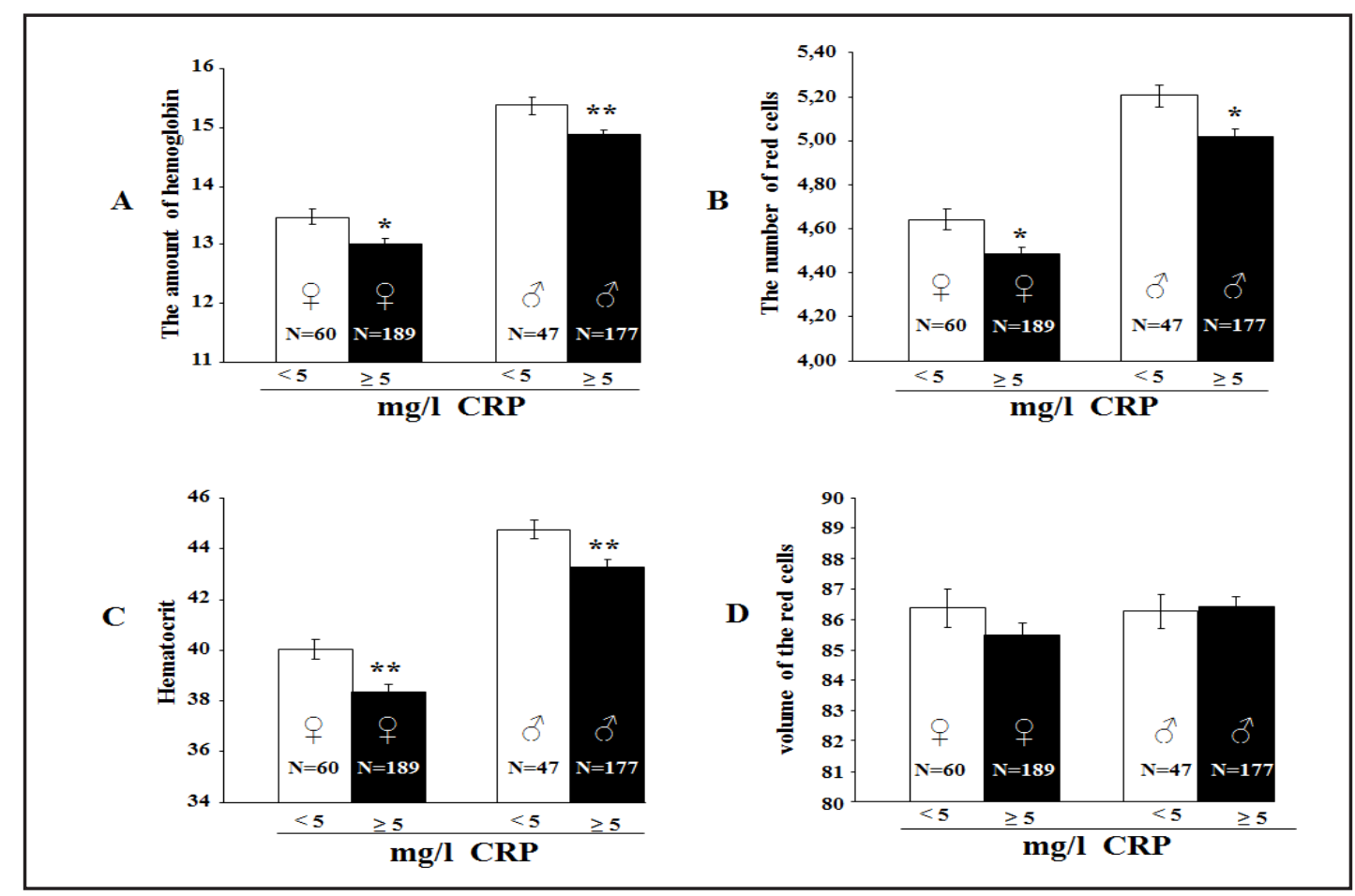

Fig. 8. Blood hemoglobin concentration, erythrocyte count, hematocrit and erythrocyte volume in blood drawn from female and male appendicitis patients with normal or high C-reactive protein. A-D. Arithmetic means \pm SEM ( $n=249$; $; 224$ ) of the hemoglobin concentration (A), erythrocyte number (B), hematocrit (C) and erythrocyte volume (D) in female (left bars) and male (right bars) patients with low (white bars) and high (black bars) levels of C-reactive protein (CRP) in plasma. ${ }^{*}(\mathrm{p}<0.05),{ }^{* *}(\mathrm{P}<0.01)$, indicates significant difference from low levels of $\mathrm{C}$-reactive protein.

volunteers to plasma drawn from patients with acute appendicitis. Moreover, the percentage of phosphatidylserine exposing erythrocytes significantly correlated with the plasma concentration of C-reactive protein. Collectively those observations strongly suggest that $\mathrm{C}$-reactive protein contributes to the stimulation of eryptosis in appendicitis patients.

Eryptosis serves to clear defective erythrocytes in order to prevent hemolysis with release of hemoglobin, which may be filtered at renal glomerula, precipitate in the acidic lumen of renal tubules and thus occlude affected nephrons [92]. To the extent that eryptosis exceeds the formation of new erythrocytes eryptosis may lead to anemia [2]. Moreover, phosphatidylserine exposing erythrocytes may interfere with microcirculation by binding to the vascular wall [69], triggering of blood clotting and induction of thrombosis [70-72], thus interfering with microcirculation [5, 70, 73-76].

In conclusion, appendicitis is paralleled by erythrocyte cell membrane scrambling with phosphatidylserine exposure to the erythrocyte surface. The effect is at least partially due to increase C-reactive protein, which increases cytosolic $\mathrm{Ca}^{2+}$ activity and ceramide formation in erythrocytes. As several inhibitors of eryptosis are available [2-4, 93, 94], eryptosis and subsequent development of anemia may be prevented.

\section{Acknowledgments}

The authors acknowledge the meticulous preparation of the manuscript by Tanja Loch. This study was supported by the Deutsche Forschungsgemeinschaft and Open Access Publishing Fund of Tuebingen University. 


\section{Cellular Physiology Cell Physiol Biochem 2017;41:806-818

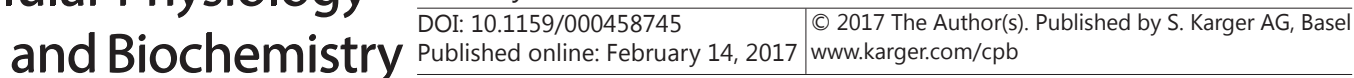 \\ Abed et al.: C-Reactive Protein and Eryptosis}

\section{Disclosure Statement}

The authors have declared no conflict of interest.

\section{References}

1 Lang PA, Kaiser S, Myssina S, Wieder T, Lang F, Huber SM: Role of $\mathrm{Ca}^{2+}$-activated $\mathrm{K}^{+}$channels in human erythrocyte apoptosis. Am J Physiol Cell Physiol 2003;285:C1553-C1560.

2 Lang E, Qadri SM, Lang F: Killing me softly - suicidal erythrocyte death. Int J Biochem Cell Biol 2012;44:1236-1243.

3 Briglia M, Antonia Rossi M, Faggio C: Eryptosis: Ally or Enemy. Curr Med Chem 2016;

4 Pretorius E, du Plooy JN, Bester J: A Comprehensive Review on Eryptosis. Cell Physiol Biochem 2016;39:1977-2000.

5 Abed M, Towhid ST, Mia S, Pakladok T, Alesutan I, Borst O, Gawaz M, Gulbins E, Lang F: Sphingomyelinaseinduced adhesion of eryptotic erythrocytes to endothelial cells. Am J Physiol Cell Physiol 2012;303:C991999.

6 Lau IP, Chen H, Wang J, Ong HC, Leung KC, Ho HP, Kong SK: In vitro effect of CTAB- and PEG-coated gold nanorods on the induction of eryptosis/erythroptosis in human erythrocytes. Nanotoxicology 2012;6:847856.

7 Maellaro E, Leoncini S, Moretti D, Del Bello B, Tanganelli I, De Felice C, Ciccoli L: Erythrocyte caspase-3 activation and oxidative imbalance in erythrocytes and in plasma of type 2 diabetic patients. Acta Diabetol 2013;50:489-495.

8 Bissinger R, Lang E, Ghashghaeinia M, Singh Y, Zelenak C, Fehrenbacher B, Honisch S, Chen H, Fakhri H, Umbach AT, Liu G, Rexhepaj R, Liu G, Schaller M, Mack AF, Lupescu A, Birnbaumer L, Lang F, Qadri SM: Blunted apoptosis of erythrocytes in mice deficient in the heterotrimeric G-protein subunit Galphai2. Sci Rep 2016;6:30925.

-9 Alzoubi K, Egler J, Abed M, Lang F: Enhanced Eryptosis Following Auranofin Exposure. Cell Physiol Biochem 2015;37:1018-1028.

10 Bissinger R, Barking S, Alzoubi K, Liu G, Liu G, Lang F: Stimulation of Suicidal Erythrocyte Death by the Antimalarial Drug Mefloquine. Cell Physiol Biochem 2015;36:1395-1405.

11 Bissinger R, Bouguerra G, Stockinger K, Abbes S, Lang F: Triggering of Suicidal Erythrocyte Death by Topotecan. Cell Physiol Biochem 2015;37:1607-1618.

12 Bouguerra G, Aljanadi O, Bissinger R, Abbes S, Lang F: Embelin-Induced Phosphatidylserine Translocation in the Erythrocyte Cell Membrane. Cell Physiol Biochem 2015;37:1629-1640.

13 Briglia M, Fazio A, Faggio C, Laufer S, Alzoubi K, Lang F: Triggering of Suicidal Erythrocyte Death by Ruxolitinib. Cell Physiol Biochem 2015;37:768-778.

14 Calabro S, Alzoubi K, Faggio C, Laufer S, Lang F: Triggering of Suicidal Erythrocyte Death Following Boswellic Acid Exposure. Cell Physiol Biochem 2015;37:131-142.

15 Egler J, Lang F: Licochalcone A Induced Suicidal Death of Human Erythrocytes. Cell Physiol Biochem 2015;37:2060-2070.

16 Faggio C, Alzoubi K, Calabro S, Lang F: Stimulation of suicidal erythrocyte death by PRIMA-1. Cell Physiol Biochem 2015;35:529-540.

17 Fazio A, Briglia M, Faggio C, Alzoubi K, Lang F: Stimulation of Suicidal Erythrocyte Death by Garcinol. Cell Physiol Biochem 2015;37:805-815.

18 Lang E, Jilani K, Bissinger R, Rexhepaj R, Zelenak C, Lupescu A, Lang F, Qadri SM: Vitamin D-Rich Diet in Mice Modulates Erythrocyte Survival. Kidney Blood Press Res 2015;40:403-412.

19 Farag MR, Alagawany M, Tufarelli V: In vitro antioxidant activities of resveratrol, cinnamaldehyde and their synergistic effect against cyadox-induced cytotoxicity in rabbit erythrocytes. Drug Chem Toxicol 2016;17:110

20 Officioso A, Alzoubi K, Manna C, Lang F: Clofazimine Induced Suicidal Death of Human Erythrocytes. Cell Physiol Biochem 2015;37:331-341.

21 Pagano M, Faggio C: The use of erythrocyte fragility to assess xenobiotic cytotoxicity. Cell Biochem Funct 2015;33:351-355.

22 Peter T, Bissinger R, Enkel S, Alzoubi K, Oswald G, Lang F: Programmed erythrocyte death following in vitro Treosulfan treatment. Cell Physiol Biochem 2015;35:1372-1380. 


\section{Cellular Physiology Cell Physiol Biochem 2017;41:806-818

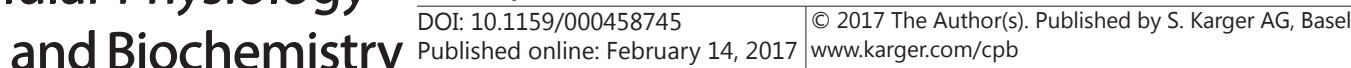

-23 Stockinger K, Bissinger R, Bouguerra G, Abbes S, Lang F: Enhanced Eryptosis Following Exposure to Carnosic Acid. Cell Physiol Biochem 2015;37:1779-1791.

-24 Waibel S, Bissinger R, Bouguerra G, Abbes S, Lang F: Saquinavir Induced Suicidal Death of Human Erythrocytes. Cell Physiol Biochem 2015;37:1973-1982.

-25 Zierle J, Bissinger R, Egler J, Lang F: Lapatinib Induced Suicidal Death of Human Erythrocytes. Cell Physiol Biochem 2015;37:2275-2287.

26 Al Mamun Bhuyan A, Bissinger R, Cao H, Lang F: Triggering of Suicidal Erythrocyte Death by Bexarotene. Cell Physiol Biochem 2016;40:1239-1251.

27 Al Mamun Bhuyan A, Bissinger R, Stockinger K, Lang F: Stimulation of Suicidal Erythrocyte Death by Tafenoquine. Cell Physiol Biochem 2016;39:2464-2476.

-28 Al Mamun Bhuyan A, Signoretto E, Bissinger R, Lang F: Stimulation of Suicidal Erythrocyte Death by Ceritinib-Treatment of Human Erythrocytes. Cell Physiol Biochem 2016;40:1129-1140.

$>29$ Al Mamun Bhuyan A, Signoretto E, Bissinger R, Lang F: Enhanced Eryptosis Following Exposure to Dolutegravir. Cell Physiol Biochem 2016;39:639-650.

-30 Almasry M, Jemaa M, Mischitelli M, Faggio C, Lang F: Stimulation of Suicidal Erythrocyte Death by Phosphatase Inhibitor Calyculin A. Cell Physiol Biochem 2016;40:163-171.

-31 Bester J, Pretorius E: Effects of IL-1beta, IL-6 and IL-8 on erythrocytes, platelets and clot viscoelasticity. Sci Rep 2016;6:32188.

-32 Bissinger R, Bhuyan AA, Signoretto E, Lang F: Stimulating Effect of Elvitegravir on Suicidal Erythrocyte Death. Cell Physiol Biochem 2016;38:1111-1120.

-33 Bissinger R, Malik A, Bouguerra G, Zhou Y, Singh Y, Abbes S, Lang F: Triggering of Suicidal Erythrocyte Death by the Antibiotic Ionophore Nigericin. Basic Clin Pharmacol Toxicol 2016;118:381-389.

-34 Egler J, Zierle J, Lang F: Stimulating Effect of Manumycin A on Suicidal Erythrocyte Death. Cell Physiol Biochem 2016;38:1147-1156.

-35 Fezai M, Slaymi C, Ben-Attia M, Lang F, Jemaa M: Purified Lesser weever fish venom (Trachinus vipera) induces eryptosis, apoptosis and cell cycle arrest. Sci Rep 2016;6:39288.

-36 Ghashghaeinia M, Giustarini D, Koralkova P, Koberle M, Alzoubi K, Bissinger R, Hosseinzadeh Z, Dreischer P, Bernhardt I, Lang F, Toulany M, Wieder T, Mojzikova R, Rossi R, Mrowietz U: Pharmacological targeting of glucose-6-phosphate dehydrogenase in human erythrocytes by Bay 11-7082, parthenolide and dimethyl fumarate. Sci Rep 2016;6:28754.

37 Jemaa M, Mischitelli M, Fezai M, Almasry M, Faggio C, Lang F: Stimulation of Suicidal Erythrocyte Death by the CDC25 Inhibitor NSC-95397. Cell Physiol Biochem 2016;40:597-607.

-38 Lang E, Pozdeev VI, Gatidis S, Qadri SM, Haussinger D, Kubitz R, Herebian D, Mayatepek E, Lang F, Lang KS, Lang PA: Bile Acid-Induced Suicidal Erythrocyte Death. Cell Physiol Biochem 2016;38:1500-1509.

39 Macczak A, Cyrkler M, Bukowska B, Michalowicz J: Eryptosis-inducing activity of bisphenol A and its analogs in human red blood cells (in vitro study). Journal of Hazardous Materials 2016;307:328-335.

40 Mischitelli M, Jemaa M, Almasry M, Faggio C, Lang F: Stimulation of Erythrocyte Cell Membrane Scrambling by Quinine. Cell Physiol Biochem 2016;40:657-667.

41 Mischitelli M, Jemaa M, Almasry M, Faggio C, Lang F: Stimulation of Suicidal Erythrocyte Death by Rottlerin. Cell Physiol Biochem 2016;40:558-566.

42 Mischitelli M, Jemaa M, Almasry M, Faggio C, Lang F: Triggering of Erythrocyte Cell Membrane Scrambling by Emodin. Cell Physiol Biochem 2016;40:91-103.

43 Mischitelli M, Jemaa M, Almasry M, Faggio C, Lang F: Triggering of Suicidal Erythrocyte Death by Fascaplysin. Cell Physiol Biochem 2016;39:1638-1647.

44 Mischitelli M, Jemaa M, Almasry M, Faggio C, Lang F: Ca2+ Entry, Oxidative Stress, Ceramide and Suicidal Erythrocyte Death Following Diosgenin Treatment. Cell Physiol Biochem 2016;39:1626-1637.

$\checkmark 4$ Officioso A, Alzoubi K, Lang F, Manna C: Hydroxytyrosol inhibits phosphatidylserine exposure and suicidal death induced by mercury in human erythrocytes: Possible involvement of the glutathione pathway. Food and Chemical Toxicology 2016;89:47-53.

46 Officioso A, Manna C, Alzoubi K, Lang F: Bromfenvinphos induced suicidal death of human erythrocytes. Pestic Biochem Physiol 2016;126:58-63.

47 Peter T, Bissinger R, Lang F: Stimulation of Eryptosis by Caspofungin. Cell Physiol Biochem 2016;39:939949.

48 Peter T, Bissinger R, Lang F: Erythrocyte Shrinkage and Cell Membrane Scrambling after Exposure to the Ionophore Nonactin. Basic Clin Pharmacol Toxicol 2016;118:107-112. 


\section{Cellular Physiology Cell Physiol Biochem 2017;41:806-818

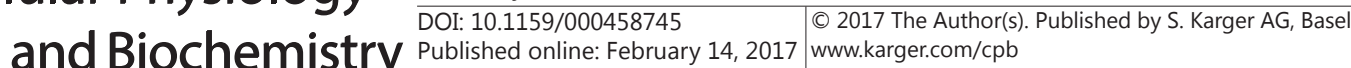

49 Peter T, Bissinger R, Liu G, Lang F: Anidulafungin-Induced Suicidal Erythrocyte Death. Cell Physiol Biochem 2016;38:2272-2284.

-50 Peter T, Bissinger R, Signoretto E, Mack AF, Lang F: Micafungin-Induced Suicidal Erythrocyte Death. Cell Physiol Biochem 2016;39:584-595.

51 Pretorius E, Bester J, Kell DB: A Bacterial Component to Alzheimer's-Type Dementia Seen via a Systems Biology Approach that Links Iron Dysregulation and Inflammagen Shedding to Disease. J Alzheimers Dis 2016;53:1237-1256.

52 Qadri SM, Chen D, Schubert P, Perruzza DL, Bhakta V, Devine DV, Sheffield WP: Pathogen inactivation by riboflavin and ultraviolet light illumination accelerates the red blood cell storage lesion and promotes eryptosis. Transfusion 2016;10.1111/trf.13959 [Epub ahead of print].

-53 Qadri SM, Donkor DA, Bhakta V, Eltringham-Smith LJ, Dwivedi DJ, Moore JC, Pepler L, Ivetic N, Nazi I, FoxRobichaud AE, Liaw PC, Sheffield WP: Phosphatidylserine externalization and procoagulant activation of erythrocytes induced by Pseudomonas aeruginosa virulence factor pyocyanin. J Cell Mol Med 2016;20:710720.

54 Signoretto E, Bissinger R, Castagna M, Lang F: Stimulation of Eryptosis by Combretastatin A4 Phosphate Disodium (CA4P). Cell Physiol Biochem 2016;38:969-981.

55 Signoretto E, Castagna M, Bhuyan AA, Lang F: Stimulating Effect of Terfenadine on Erythrocyte Cell Membrane Scrambling. Cell Physiol Biochem 2016;38:1425-1434.

-56 Signoretto E, Castagna M, Lang F: Stimulation of Eryptosis, the Suicidal Erythrocyte Death by Piceatannol. Cell Physiol Biochem 2016;38:2300-2310.

57 Signoretto E, Honisch S, Briglia M, Faggio C, Castagna M, Lang F: Nocodazole Induced suicidal death of human erythrocytes. Cell Physiol Biochem. 2016;38:379-392.

58 Signoretto E, Zierle J, Bhuyan AA, Castagna M, Lang F: Ceranib-2-induced suicidal erythrocyte death. Cell Biochem Funct 2016;34:359-366.

-59 Signoretto E, Zierle J, Bissinger R, Castagna M, Bossi E, Lang F: Triggering of Suicidal Erythrocyte Death by Pazopanib. Cell Physiol Biochem 2016;38:926-938.

-60 Waibel S, Bissinger R, Bouguerra G, Abbes S, Lang F: Ritonavir-Induced Suicidal Death of Human Erythrocytes. Basic Clin Pharmacol Toxicol 2016;119:51-57.

61 Xu D, Ran Q, Xiang Y, Linhai J, Smith BM, Bou-Abdallah F, Lund R, Li Z, Dong H: Toward Hemocompatible Self-assembling Antimicrobial Nanofibers: Understanding the Synergistic Effect of Supramolecular Structure and PEGylation on Hemocompatibility. RSC Adv 2016;6:15911-15919.

62 Zierle J, Bissinger R, Bouguerra G, Abbes S, Lang F: Triggering of Suicidal Erythrocyte Death by Regorafenib. Cell Physiol Biochem 2016;38:160-172.

63 Al Mamun Bhuyan A, Signoretto E, Lang F: Triggering of Suicidal Erythrocyte Death by Psammaplin A. Cell Physiol Biochem 2016;39:908-918.

64 Lupescu A, Bissinger R, Goebel T, Salker MS, Alzoubi K, Liu G, Chirigiu L, Mack AF, Qadri SM, Lang F: Enhanced suicidal erythrocyte death contributing to anemia in the elderly. Cell Physiol Biochem 2015;36:773-783.

65 Wesseling MC, Wagner-Britz L, Huppert H, Hanf B, Hertz L, Nguyen DB, Bernhardt I: Phosphatidylserine Exposure in Human Red Blood Cells Depending on Cell Age. Cell Physiol Biochem 2016;38:1376-1390.

66 Chang AL, Hoehn RS, Jernigan P, Cox D, Schreiber M, Pritts TA: Previous Cryopreservation Alters the Natural History of the Red Blood Cell Storage Lesion. Shock 2016;46:89-95.

67 Lang E, Pozdeev VI, Xu HC, Shinde PV, Behnke K, Hamdam JM, Lehnert E, Scharf RE, Lang F, Haussinger D, Lang KS, Lang PA: Storage of Erythrocytes Induces Suicidal Erythrocyte Death. Cell Physiol Biochem 2016;39:668-676.

-68 Larsson A, Hult A, Nilsson A, Olsson M, Oldenborg PA: Red blood cells with elevated cytoplasmic Ca(2+) are primarily taken up by splenic marginal zone macrophages and CD207+ dendritic cells. Transfusion 2016;56:1834-1844.

69 Borst O, Abed M, Alesutan I, Towhid ST, Qadri SM, Foller M, Gawaz M, Lang F: Dynamic adhesion of eryptotic erythrocytes to endothelial cells via CXCL16/SR-PSOX. Am J Physiol Cell Physiol 2012;302:C644-C651.

70 Andrews DA, Low PS: Role of red blood cells in thrombosis. Curr Opin Hematol 1999;6:76-82.

-71 Chung SM, Bae ON, Lim KM, Noh JY, Lee MY, Jung YS, Chung JH: Lysophosphatidic acid induces thrombogenic activity through phosphatidylserine exposure and procoagulant microvesicle generation in human erythrocytes. Arterioscler Thromb Vasc Biol 2007;27:414-421. 


\section{Cellular Physiology Cell Physiol Biochem 2017;41:806-818

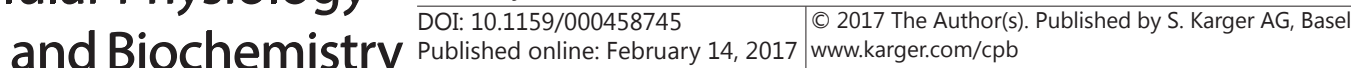

Abed et al.: C-Reactive Protein and Eryptosis

-72 Zwaal RF, Comfurius P, Bevers EM: Surface exposure of phosphatidylserine in pathological cells. Cell Mol Life Sci 2005;62:971-988.

73 Closse C, Dachary-Prigent J, Boisseau MR: Phosphatidylserine-related adhesion of human erythrocytes to vascular endothelium. Br J Haematol 1999;107:300-302.

-74 Gallagher PG, Chang SH, Rettig MP, Neely JE, Hillery CA, Smith BD, Low PS: Altered erythrocyte endothelial adherence and membrane phospholipid asymmetry in hereditary hydrocytosis. Blood 2003;101:46254627.

75 Pandolfi A, Di Pietro N, Sirolli V, Giardinelli A, Di Silvestre S, Amoroso L, Di Tomo P, Capani F, Consoli A, Bonomini M: Mechanisms of uremic erythrocyte-induced adhesion of human monocytes to cultured endothelial cells. J Cell Physiol 2007;213:699-709.

76 Wood BL, Gibson DF, Tait JF: Increased erythrocyte phosphatidylserine exposure in sickle cell disease: flowcytometric measurement and clinical associations. Blood 1996;88:1873-1880.

77 Bissinger R, Artunc F, Qadri SM, Lang F: Reduced Erythrocyte Survival in Uremic Patients Under Hemodialysis or Peritoneal Dialysis. Kidney Blood Press Res 2016;41:966-977.

78 Bissinger R, Kempe-Teufel DS, Honisch S, Qadri SM, Randrianarisoa E, Haring HU, Henes J, Lang F: Stimulated Suicidal Erythrocyte Death in Arteritis. Cell Physiol Biochem 2016;39:1068-1077.

79 Bissinger R, Schumacher C, Qadri SM, Honisch S, Malik A, Gotz F, Kopp HG, Lang F: Enhanced eryptosis contributes to anemia in lung cancer patients. Oncotarget 2016;7:14002-14014.

-80 Bonan NB, Steiner TM, Kuntsevich V, Virzi GM, Azevedo M, Nakao LS, Barreto FC, Ronco C, Thijssen S, Kotanko P, Pecoits-Filho R, Moreno-Amaral AN: Uremic Toxicity-Induced Eryptosis and Monocyte Modulation: The Erythrophagocytosis as a Novel Pathway to Renal Anemia. Blood Purif 2016;41:317-323.

-81 Crisp RL, Vota DM, Donato H, Garcia E, Rapetti MC, Maltaneri RE, Vittori DC, Nesse AB: Eryptosis is induced by hyperthermia in hereditary spherocytosis red blood cells. Clin Chem Lab Med 2016;54:e165-168.

82 Hortle E, Nijagal B, Bauer DC, Jensen LM, Ahn SB, Cockburn IA, Lampkin S, Tull D, McConville MJ, McMorran BJ, Foote SJ, Burgio G: Adenosine monophosphate deaminase 3 activation shortens erythrocyte half-life and provides malaria resistance in mice. Blood 2016;128:1290-1301.

-83 Jiang P, Bian M, Ma W, Liu C, Yang P, Zhu B, Xu Y, Zheng M, Qiao J, Shuai Z, Zhou X, Huang D: Eryptosis as an Underlying Mechanism in Systemic Lupus Erythematosus-Related Anemia. Cell Physiol Biochem 2016;40:1391-1400.

84 Rohrig G: Anemia in the frail, elderly patient. Clin Interv Aging 2016;11:319-326.

-85 Foller M, Braun M, Qadri SM, Lang E, Mahmud H, Lang F: Temperature sensitivity of suicidal erythrocyte death. Eur J Clin Invest 2010;40:534-540.

86 Gendel I, Gutermacher M, Buklan G, Lazar L, Kidron D, Paran H, Erez I: Relative value of clinical, laboratory and imaging tools in diagnosing pediatric acute appendicitis. Eur J Pediatr Surg 2011;21:229-233.

-87 Drake FT, Flum DR: Improvement in the diagnosis of appendicitis. Adv Surg 2013;47:299-328.

88 Shogilev DJ, Duus N, Odom SR, Shapiro NI: Diagnosing appendicitis: evidence-based review of the diagnostic approach in 2014. West J Emerg Med 2014;15:859-871.

89 Thiele JR, Zeller J, Bannasch H, Stark GB, Peter K, Eisenhardt SU: Targeting C-Reactive Protein in Inflammatory Disease by Preventing Conformational Changes. Mediators Inflamm 2015;2015:372432.

-90 Wu Y, Potempa LA, El Kebir D, Filep JG: C-reactive protein and inflammation: conformational changes affect function. Biol Chem 2015;396:1181-1197.

91 Blaschke F, Bruemmer D, Yin F, Takata Y, Wang W, Fishbein MC, Okura T, Higaki J, Graf K, Fleck E, Hsueh WA, Law RE: C-reactive protein induces apoptosis in human coronary vascular smooth muscle cells. Circulation 2004;110:579-587.

$\$ 92$ Harrison HE, Bunting H, Ordway NK, Albrink WS: The Pathogenesis of the Renal Injury Produced in the Dog by Hemoglobin or Methemoglobin. J Exp Med 1947;86:339-356.

93 Shan F, Yang R, Ji T, Jiao F: Vitamin C Inhibits Aggravated Eryptosis by Hydrogen Peroxide in Glucose-6Phosphated Dehydrogenase Deficiency. Cell Physiol Biochem 2016;39:1453-1462.

$\$ 94$ Zierle J, Bissinger R, Lang F: Inhibition by Teriflunomide of Erythrocyte Cell Membrane Scrambling Following Energy Depletion, Oxidative Stress and Ionomycin. Cell Physiol Biochem 2016;39:1877-1890. 